\title{
The Influence of Return On Assets, Return On Equity, Debt Equity Ratio on Dividend Policy of Pharmaceutical Companies Listed on the Indonesia Stock Exchange Period 2014-2017
}

\author{
Eka Septa Kurniawan $^{1}$, Agus Sukoco², Joko Suyono ${ }^{2}$ \\ ekasepta1693@gmail.com¹, agus.sukoco@narotama.ac.id ${ }^{2}$,joko.suyono@narotama.ac.id ${ }^{3}$ \\ Departement of Management, Faculty Economics and Business, Narotama University, Jl Arif Rahman \\ Hakim No 51 Surabaya, Indonesia ${ }^{1,2,3}$
}

\begin{abstract}
This study aims to analyze the effect of Return On Assets, Return On Equity, Debt Equity Ratio on policies in viden. The study of retrieving data from financial statements of pharmaceutical companies that have been listed on the Indonesia Stock Exchange for the period 2014 - 2017. This type of research used in this research is quantitative research. The data collection technique used in this research is the documentation data collection technique, a measuring instrument to find out the company's dividend policy in this study, which is using Dividend Pay o ut Ratio. From the results of this study it can be concluded that the ROA, ROE, and DER that we call the independent variable (X) have a significant effect and are positive for the DPR or what we call the dependent variable (Y).
\end{abstract}

Keywords: Return On Assets , Return On Equity , Debt Equity Ratio

\section{INTRODUCTION}

The pharmaceutical industry is a science-based industry engaged in medicine. Currently Indonesian pharmaceutical companies are required to develop, so they are able to compete with foreign pharmaceutical companies so that they can win the market by making a good distribution system, as well as optimal product quality. But in the latest news quoted from kompas.com pharmaceutical companies in Indonesia have experienced delays or even can have decreased, if four years ago the growth of the pharmaceutical world ranged from 15-20\%, three years ago it has fallen maybe below 15\%, even pharmaceutical growth in Indonesia in the past two years it did not reach 5\% (said the head of the joint pharmacy company Indonesian committee, Vincent Harijanto, 2018). The decline was also experienced by two major pharmaceutical companies in Indonesia, first PT. Kalbe Farma, this company experienced a delay in business growth from the period 2015 - 2016 reaching 14.7\%, while 2016 - 2017 the company's sales growth was only around 4.5\%. Both PT. Kimia Farma, Tbk also experienced the same thing where the period of 2015 - 2016 revenue growth reached $21.36 \%$, and in the following year, growth became $17.8 \%$.

Of course, to make progress and increase, there is a need for funding, the funding is obtained from investors. In general, investors have the main goal to improve welfare and obtain high returns from investment returns. The return obtained by investors is dividend income. On the other hand, the company also expects continuous growth to maintain the continuity of the pharmaceutical company itself, which at the same time must provide greater welfare to shareholders.

Of course, to make progress and increase, there is a need for funding, the funding is obtained from investors. In general, investors have the main goal to improve welfare and obtain high returns from investment returns. The return obtained by investors is dividend income. On the other hand, the company also expects continuous growth to maintain the continuity of the pharmaceutical company itself, which at the same time must provide greater welfare to shareholders.

Dividend policy related to funding if the investment is mostly funded by internal equity will affect the amount of dividends distributed. The greater the investment, the less dividends are distributed and if the internal equity funds are insufficient from the funds needed for investment, then it can be fulfilled from the external, especially from the stock (Kurniadi, 2010). Based on the background described above, the problems that will be examined in this study can be determined, namely:

1. Does ROA partially influence dividen policy on pharmaceutical companies listed on the Indonesia Stock Exchange Period 2014-2017? 
2. Does ROE partially influence dividen policy on pharmaceutical companies listed on the Indonesia Stock Exchange Period 2014-2017?

3. Does DER partially influence dividen policy on pharmaceutical companies listed on the Indonesia Stock Exchange Period 2014-2017?

4. Does ROA, ROE, DER simultaneously influence dividen policy on pharmaceutical companies listed on the Indonesia Stock Exchange Period 2014-2017?

\section{LITERATURE REVIEWS AND HYPOTHESES}

The test results influence the leverage variable (DER) on dividend policy (DPR), shows that the regression coefficient is $-0,170$ and the tcount is $-2,070$ with a significance of 0.040 . The significance level is 0.040 smaller of $\alpha=0.05$ and tcount is greater than $t$ table. The results of this study indicate that the variable debt to equity ratio has a negative and significant to dividend policy. This indicates that if the level of debt is higher to equity ratio, manufacturing companies tend to to hold the profits earned to pay off debt or use it as a source of funds internal to maintain the balance of the capital structure company. (Deni, Aisjah, \& Djazuli, 2016).

Data analysis used panel data regression fixed effect which had larger $\mathrm{R}$ square value. The results showed that current ratio, return on assets, debt to equity ratio, earnings growth, return on equity, earnings per share and market to book value simultaneously were having significant influence to the dividend payout ratio. Return on equity affects dividend payout the ratio of pharmaceutical companies is negative and significant. (Zulkifli, Endri, \& Kurniasih, 2019)

Partially Debt to Equity Ratio (DER) has an effect on the Dividend Payout Ratio (DPR) because there is a Debt to Equity Ratio that can reflect the company's ability to fulfill its obligations through its own capital. Increased liabilities will affect the size of net income, including dividends paid. If the debt burden gets smaller, then the company's ability to divide dividends will be higher, because with a high level of debt, of course the interest expense will also be small and indirectly affect the earnings movement of the company. higher, so that indirectly DER is able to influence movement from the Dividend Payout Ratio (DPR). (Winarko, 2017)

Results of t-test known that the Return On Asset (ROA) to the stock price has a significant influence and positive relationship. Currently, earnings before interest and taxes rose and total assets down the ROA will rise, the greater the ROA greater level of profit achieved by the company. This shows that management can use the total assets of the company as well (current assets and fixed assets) and will ultimately improve the company's stock price so that attract many investors to invest in the insurance company. (Manoppo, 2015)

Current Ratio has no effect on dividend payout ratio in sub sector automotive and component. Debt to Equity Ratio has an effect on dividend payout ratio. Return on Asset has an effect on dividend payout ratio in sub sector automotive and component of period 2012-2016. (Herawati \& Irradha Fauzia, 2018)

\section{Return On Assets (ROA)}

Return On Assets illustrates the extent to which the ability of assets owned by a company can generate profits. (Tandelilin, 2010)

$$
\text { ROA }=\frac{\text { Net Income After Tax }}{\text { Total assets }}
$$

\section{Return On Equity (ROE)}

Return On Equity is the return on equity (Return On Equity) is a comparison between net income and equity. (Bambang Riyanto, 2010)

$$
\text { ROE }=\frac{\text { Profit After Interest and Tax }}{\text { Capital }}
$$

\section{Debt Equity Ratio (DER)}

Debt to equity ratio (DER) is the ratio used to assess debt with equity. This ratio is sought by comparing all debt, including current debt with all equity. This ratio states that the higher the ratio, means the equity is less than the debt ". (Hanafi, 2012)

$$
\text { DER }=\frac{\text { Total Debt }}{\text { Total Equity }}
$$




\section{Dividend Payout Ratio (DPR)}

Dividend policy is all managerial policies carried out to determine how much net profit is shared with Total Asset Net Profit, Return on Assets to shareholders and how much net income remains to be held for investment reserves next year. The policy is reflected in the magnitude of the ratio of profits paid as dividends to net income (dividend payout). (Handono mardiyanto, 2009)

Dividend Payout Ratios are a small part of corporate funding decisions. The DPR is used in the share valuation model to estimate dividends paid in the future. (Abdul Hanafi dan Mamduh M. Hanafi, 2009)

$$
\text { DPR }=\frac{\text { Dividends Per Share }}{\text { Net Income Per Share }}
$$

\section{Hypothesis}

The formulation of the research hypothesis is research that uses quantitative. The hypothesis is an answer to the research problem formulation, while the research problem formulation has been approved in the form of approving times (sugiyono, 2017)

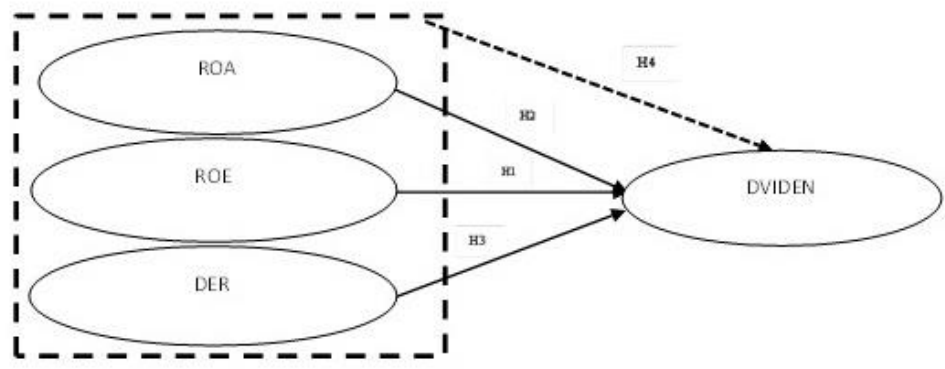

INFORMATION :

Figure 1. Research Model

: Simultan

: Parsial

The hypothesis is a temporary answer to the research problem, until proven through the collected data (Arikunto, 2006). Based on the theoretical basis and the framework of thinking that has been described above, the hypothesis of this study are:

1. ROA partially influence dividen policy on pharmaceutical companies listed on the Indonesia Stock Exchange Period 2014-201

2. ROE partially influence dividen policy on pharmaceutical companies listed on the Indonesia Stock Exchange Period 2014-2017

3. DER partially influence dividen policy on pharmaceutical companies listed on the Indonesia Stock Exchange Period 2014-2017

4. ROA, ROE, DER simultaneously influence dividen policy on pharmaceutical companies listed on the Indonesia Stock Exchange Period 2014-2017

\section{Types of research}

\section{METHODS}

The type of research used in this study is quantitative research methods. Where quantitative research is a process of finding knowledge that uses data in the form of numbers as a tool to analyze information about what you want to know. (Kasiram, 2008)

\section{Population}

Definition of population according to is a region of generalization consisting of objects / subjects that possess the quality and characteristics set by the researcher to be studied and then concluded (Sugiyono, 2008). The population in this study is a engaged in the pharmaceutical or pharmaceutical sector which is listed on the Indonesia Stock Exchange for the period 2014-2017.

Sample

The sample in this study is Saturated Sampling, which is all 9 pharmaceutical companies listed on the Stock Exchange in 2014 - 2017 as many as 9 companies. 


\section{Data Type}

To be able to maximize this research, the types and sources of data used for this research are quantitative types of data where the data can be measured or calculated directly, in the form of information or explanations expressed in numbers or in the form of numbers.(Sugiyono, 2013)

\section{Data Source}

Sources of data from this study are secondary data. Secondary data is data collected by researchers obtained from second parties and neatly arranged in the form of documents and obtained from www.idx.co.id. Data taken from pharmaceutical companies' financial statements for the period 2014-2017.

\section{Data Collection}

According to data retrieval techniques are the most strategic step in research, because the main purpose of research is to obtain data. In this study the data collection techniques used the Literature Technique and Documentation Technique. (Sugiyono, 2013)

\section{Data Analysis Technique}

As explained earlier that this study uses a quantitative approach, the analytical technique used for this study is multiple linear analysis, where the technique is one of the analytical tools regarding dependent variable dependence $(\mathrm{Y})$ on several independent variables $(\mathrm{X})$. The purpose of the use of the linear regression equation is to interpret the dependent variable on the independent variable. Data management in this study uses the Statistical Product and Service Solutions (SPSS) program.

The multiple linear regression equation model with the formula as follows:

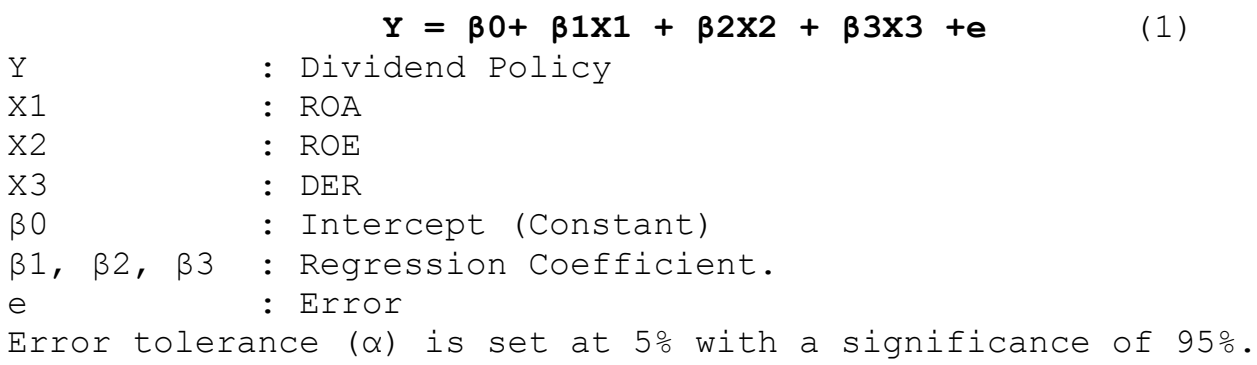

\section{RESULT AND DISCUSSION}

\section{Descriptive Statistics}

Table 1: Descriptive Statistics Results

\begin{tabular}{|l|c|c|c|c|c|}
\hline & $\mathbf{N}$ & Min & Max & Mean & Std Deviation \\
\hline ROA & 36 & 0.00 & 3.63 & 0.2342 & 0.63600 \\
\hline ROE & 36 & 0.00 & 4.99 & 0.2658 & 0.81857 \\
\hline DER & 36 & 0.03 & 1.911 & 0.5363 & 0.45446 \\
\hline Valid N (listwise) & 36 & & & & \\
\hline
\end{tabular}

Based on the descriptive table statistics above shows that of the 9 pharmaceutical companies listed on the Stock Exchange for a period of 4 years namely 2014-2017,

From the data above shows that X1 has a minimum value of 0.00 and a maximum value of 3.63 , and an average value of 0.2342 with a standard deviation of 0.63600 .

$\mathrm{X} 2$ has a minimum value of 0.00 and a maximum value of 4.99 , with an average value of 0.2658 with a standard deviation of 0.81857 .

While X3 has a minimum value of 0.03 and a maximum value of 1.91 , has an average value of 0.5363 and has a standard deviation value of 0.45446 .

\section{Multicollinearity Test}

Tabel 2: Multicollinearity Test Results

\begin{tabular}{|l|c|c|}
\hline \multirow{2}{*}{ Model } & \multicolumn{2}{|c|}{ Collinearity Statistics } \\
\cline { 2 - 3 } & Tolerance & VIF \\
\hline
\end{tabular}




\begin{tabular}{|l|c|c|} 
Constant & & \\
ROA & 0.080 & 12.548 \\
ROE & 0.086 & 11.561 \\
DER & 0.756 & 1.323 \\
\hline
\end{tabular}

The results of VIF in table 4.4 show that the tolerance value of the ROA variable is 0.080 smaller than 0.10 and the VIF value of 12.548 is greater than 10.00 so, the ROA variable has a multicollinearity problem. The ROE variable tolerance value is 0.086 smaller than 0.10 and the VIF value of 5.561 is greater than 10.00 so, the ROE variable also has a multicollinearity problem. And the DER variable tolerance value of 0.756 is greater than 0.10 and the VIF value of 1.323 is smaller than 10.00 so it can be concluded that the DER variable does not occur multicollinearity.

\section{Heteroscedasticity Test}

Tabel 3: Heteroscedasticity Test Results

\begin{tabular}{|c|c|c|}
\hline Model & $\mathbf{t}$ & Sig. \\
\hline Constant & 1.974 & 0.105 \\
\hline ROA & -0.854 & 0.432 \\
\hline ROE & 0.497 & 0.640 \\
\hline DER & -0.272 & 0.796 \\
\hline
\end{tabular}

Based on the test results above the significance value of the ROA variable is 0.432 . The significance value of ROE is 0.640 and the significance value for DER is 0.796 . Because the significance value of the three independent variables is greater than 0.05 , it can be concluded that the regression model in this study did not occur heteroscedasticity.

\section{Autocorrelation Test}

Tabel 4: Autocorrelation Test Results

Model Summary

\begin{tabular}{|c|c|c|c|c|c|}
\hline Model & R & R Square & $\begin{array}{c}\text { Adjusted R } \\
\text { Square }\end{array}$ & $\begin{array}{c}\text { Std error of } \\
\text { the Estimate }\end{array}$ & $\begin{array}{c}\text { Durbin- } \\
\text { watson }\end{array}$ \\
\hline 1 & $0.909^{\mathrm{a}}$ & 0.827 & 0.723 & 0.18051 & 3.034 \\
\hline
\end{tabular}

From the results of the autocorrelation test above, the value of durbin watson is 3.034. And the value of $\mathrm{dL}$ or the lower limit of 1.2953 and the value of $\mathrm{dU}$ or the upper limit of 1.6539 and the 4-dU value are 2.3461. Thus it can be concluded that autocorrelation occurs because the value of durbin watson is greater than the 4-dU value.

\section{Normality Test}

One Sample Kolmogrov Smirnov Test

\begin{tabular}{|ll|r|}
\hline & & \multicolumn{1}{|c|}{$\begin{array}{c}\text { Undstandardized } \\
\text { Residual }\end{array}$} \\
\hline $\mathrm{N}$ & & 9 \\
Normal Parameters & Mean & 0.000000 \\
& Std Deviation & 0.14270963 \\
Most Extreme Different & Absolute & 0.201 \\
& Positive & 0.142 \\
& Negative & -0.201
\end{tabular}




\begin{tabular}{l|l|r|c}
$\begin{array}{c}\text { Tabel 5: } \\
\text { Test }\end{array}$ & Kolmogrov Smirnov Z & 0.602 & $\begin{array}{c}\text { Normality } \\
\text { Results }\end{array}$ \\
\cline { 2 - 3 } & Asymp. Sig (2 tailed) & 0.862 &
\end{tabular}

Based on the results in the table above the value of Asymp. Sig is 0.862. Because, the value of Asymp. Sig greater than 0.05 , the distribution of variables in this study is declared normal.

Simultaneous Hypothesis Test (F Test)

Tabel 6: F Test Results

\begin{tabular}{|l|c|c|c|c|c|}
\hline \multicolumn{1}{|c|}{ Model } & ANOVA & & & \\
& Sum of & & Mean \\
Squares & df & Square & F & Sig. \\
\hline Regression & 0.778 & 3 & 0.259 & 7.963 & $0.024^{\mathrm{a}}$ \\
Residual & 0.163 & 5 & 0.033 & & \\
Total & 0.94 & 8 & & & \\
\hline
\end{tabular}

Based on the above calculations that Fcount $=7.963$ is greater than Ftable $=4.76$ and the significance level is 0.024 less than 0.05 . So, this shows that the hypothesis is accepted, where all $\mathrm{X}$ variables together have a simultaneous effect on variable Y.

\section{Partial Hypothesis Test (t Test)}

Tabel 7: t Test Results

Coefficients

\begin{tabular}{|l|c|c|c|c|c|}
\hline \multirow{2}{*}{ Model } & \multicolumn{2}{|c|}{$\begin{array}{c}\text { Undstandardized } \\
\text { Coefficient }\end{array}$} & $\begin{array}{c}\text { Standardized } \\
\text { Coefficient }\end{array}$ & & \\
\cline { 2 - 4 } & B & Std Error & Beta & t & Sig. \\
\hline Constant & 0.690 & 0.129 & & 5.357 & 0.003 \\
ROA & -0.700 & 0.594 & -0.776 & -1.178 & 0.292 \\
ROE & 0.842 & 0.436 & 1.221 & 1.931 & 0.111 \\
DER & -0.555 & 0.164 & -0.723 & -3.377 & 0.020 \\
\hline
\end{tabular}

Based on the table above the ROA variable has a significant value of 0.292 and the value of $\mathrm{t}-1.178$. significant value of ROE is 0.111 and $t$ value is 1.931 . while the significant value of DER is 0.020 and the value of $t-3.377$. The value of t table can be searched using the formula $t$ table $=(\alpha / 2$; df residual $)$ obtained by numbers $(0.025 ; 5)$ In the distribution table it is known that the value of $t$ table is 2.571 .

\section{Determination Coefficient Test $\left(\mathbf{R}^{2}\right)$}

Tabel 8: Determination Coefficient Test Results

\begin{tabular}{|c|c|c|c|c|}
\hline \multicolumn{2}{|c|}{ Model Summary } \\
\hline 1 & R & R Square & $\begin{array}{c}\text { Adjusted R } \\
\text { Square }\end{array}$ & $\begin{array}{c}\text { Std error of the } \\
\text { Estimate }\end{array}$ \\
\hline
\end{tabular}

Based on the table above has the value of $\mathrm{R}$ Square or the coefficient of determination is 0.827 . It can be concluded that the independent variables in this study affect the required variables by $82.7 \%$.

\section{Multiple Linear Regression Analysis}


Tabel 9: Summary of Results of Multiple Linear Regression Analysis

\begin{tabular}{|lrrrr|}
\hline \multicolumn{5}{|c|}{ Summary of Results of Multiple Linear Regression Analysis } \\
\hline & Variable & Regression Coefficient & t count & \multicolumn{1}{c|}{ Sig } \\
\hline Constant & 0.690 & 5.357 & 0.003 \\
ROA & -0.700 & -1.178 & 0.292 \\
ROE & 0.842 & 1.931 & 0.111 \\
DER & -0.555 & -3.377 & 0.020 \\
\hline F count & 7.963 & & \\
R Square & 0.827 & & \\
\hline
\end{tabular}

Based on the results of SPSS data processing, a constant coefficient value of 0.690 was obtained, for ROA the coefficient value was $-0,700$, the coefficient of ROE was 0.842 , and the DER coefficient was -

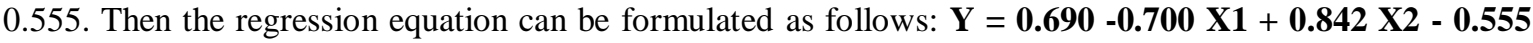
X3

After the classic assumption test and hypothesis test conducted in the previous sub-chapter, the results obtained from the method of multiple linear regression analysis in the study " Influence of ROA, ROE, DER on dividend policy in pharmaceutical companies in 2014 - 2017. Furthermore the results of multiple linear regression analysis will be discussed clearly in this sub-chapter each independent variable is dependent on the variable :

Influence of ROA on the Dividend Policy

Based on the results of research with SPSS software, it can be concluded that ROA has no effect and is negative towards the DPR. ROA in this study has no effect.

The results of this study are different from the results of research (Winarko, 2017), where the results of his research Return On Assets have a significant effect on Dividend Payout Ratio (DPR) because there is a tendency for the value of ROA to be high enough to mean a return of sufficient assets.

\section{Influence of ROE on the Dividend Policy}

Based on the results of the study it can be concluded that ROE does not affect the DPR and has a positive value to the DPR.

The results of this study contradict the results of the study (Zulkifli et al., 2019). Where the results of the research showed a negative and significant effect.

Influence of DER on the Dividend Policy

The results of this study indicate that DER has a significant effect on the DPR and has a negative value towards the DPR.

The results of this study are the same as the results of previous studies conducted by (Herawati \& Irradha Fauzia, 2018). wwhere the results of the research, namely DER have a significant influence on the DPR.

\section{Influence of ROA, ROE, DER on the Dividend Policy}

From the results of this study, it can be concluded that the ROA, ROE, and DER that we call the independent variable $(\mathrm{X})$ have a significant effect and are positive for the DPR or what we call the dependent variable (Y).

\section{CONCLUSION}

Based on the results of data analysis obtained from the results of 9 samples of pharmaceutical companies received on the IDX reported in the analysis of related data in the previous chapter, conclusions can be taken as follows:

1. The results of the Multicollinearity test show the value of the ROA variable is 0.080 smaller than 0.10 and the VIF value of 12.548 is greater than 10.00 then, the ROA variable uses the problem of multicollinearity. The ROE variable is more than 0.086 less than 0.10 and the VIF value of 9.561 is greater than 10.00 so, the ROE variable also has a multicollinearity problem. And the DER variable value of 0.756 is greater than 0.10 and the VIF value of 1.323 is smaller than 10.00 so it can be concluded that the DER variable does not occur multicollinearity. 
2. The results that show that ROA (X1), ROE (X2), DER (X3), are simultaneously related simultaneously to variable Y, where calculating according to FCount $=7.963$ is greater than Ftable $=$ 4.76 and significance 0.024 less than 0.05 .

3. The results of the t test, namely ROA (X1) Ho are accepted and $\mathrm{H} 1$ is rejected, meaning that partial ROA is not approved of the DPR. ROE (X2) Ho is accepted and H2 is rejected, meaning that ROE is not partial against the DPR. DER (X3). Ho is rejected and H3 is accepted, meaning that DER has an influence on the DPR

4. Based on the results of the test $\mathrm{r}$ R Square or the coefficient of determination is 0.827 . It can be concluded that the independent variables in this study affect the required variables by $82.7 \%$.

\section{REFERENCE}

Abdul Hanafi dan Mamduh M. Hanafi. (2009). Analisis Laporan Keuangan (4th ed.). Yogyakarta.

Bambang Riyanto. (2010). Dasar-Dasar Pembelanjaan Perusahaa (4th ed.). YOGYAKARTA.

Deni, F. F., Aisjah, S., \& Djazuli, A. (2016). Analisis Variabel-Variabel yang Mempengaruhi Kebijakan Dividen (Studi pada Perusahaan Manufaktur yang Terdaftar di Bursa Efek Indonesia). Jurnal Aplikasi Manajemen. https://doi.org/10.18202/jam23026332.14.2.17

Hanafi, M. dan A. H. (2012). Analisis Laporan Keuangan. Yogyakarta.

Handono mardiyanto. (2009). Intisari Manajemen Keuangan. Jakarta.

Herawati, A., \& Irradha Fauzia, F. (2018). The Effect of Current Ratio, Debt to Equity Ratio and Return on Asset on Dividend Payout Ratio in Sub-sector Automotive and Component Listed in Indonesia Stock Exchange in Period 2012-2016. KnE Social Sciences, 3(10), 1076-1086. https://doi.org/10.18502/kss.v3i10.3450

Kasiram, M. (2008). Metode Penelitian Kuantitatif-Kualitatif. In Metode Penelitian Kuantitatif-Kualitatif. Malang: UIN Malang Press.

Kurniadi, H. (2010). Strategi Pembelajaran Inquiri Sosial.

Manoppo, C. P. (2015). the Influence of Roa, Roe, Ros, and Eps on Stock Price. Emba.

sugiyono. (2017). metode sem.

Sugiyono. (2008). Metode Penelitian Kunatitatif Kualitatif dan R\&D. bandung: Alfabeta.

Sugiyono. (2013). Metode Penelitian Kuantitatif, Kualitatif dan R\&D. In Metode Penelitian (p. 224). bandung: Alfabeta.

Tandelilin, E. (2010). Dasar-dasar Manajemen Investasi. Keuangan.

Winarko, S. P. (2017). Pengaruh Cash Ratio, Debt To Equity Ratio, Return On Assets, Dan Tax Rate Terhadap Dividend Payout Ratio Pada Perusahaan Manufaktur Yang Terdaftar Di Bursa Efek Indonesia. JURNAL AKUNTANSI \& EKONOMI FE. UN PGRI Kediri.

Zulkifli, Z., Endri, E., \& Kurniasih, A. (2019). DETERMINAN INTERNAL DIVIDEND PAYOUT RATIO PERUSAHAAN FARMASI TERDAFTAR DI BURSA EFEK INDONESIA. Jurnal Keuangan Dan Perbankan. https://doi.org/10.26905/jkdp.v21i2.311 